\title{
Therapeutic Targeting of Classical and Lectin Pathways of Complement Protects from Ischemia-Reperfusion-Induced Renal Damage
}

\author{
Giuseppe Castellano, ${ }^{*}$ Rita Melchiorre, ${ }^{*}$ \\ Antonia Loverre, ${ }^{*}$ Pasquale Ditonno, ${ }^{\dagger}$ \\ Vincenzo Montinaro, ${ }^{*}$ Michele Rossini, ${ }^{*}$ \\ Chiara Divella, ${ }^{*}$ Michele Battaglia, ${ }^{\dagger}$ \\ Giuseppe Lucarelli, ${ }^{\dagger}$ Gennaro Annunziata, ${ }^{\dagger}$ \\ Silvano Palazzo, ${ }^{\dagger}$ Francesco Paolo Selvaggi, ${ }^{\dagger}$ \\ Francesco Staffieri, ${ }^{\ddagger}$ Antonio Crovace, ${ }^{\ddagger}$ \\ Mohamed R. Daha, ${ }^{\S}$ Maurice Mannesse, ${ }^{\pi}$ \\ Sandra van Wetering, ${ }^{\text {"T }}$ Francesco Paolo Schena, ${ }^{*}$ \\ and Giuseppe Grandaliano*

\begin{abstract}
From the Renal, Dialysis and Transplantation Unit," Urology, Andrology and Renal Transplantation Unit, ${ }^{\dagger}$ Veterinary Sungery Unit, ${ }^{\ddagger}$ University of Bari, Bari, Italy; the Department of Nephrology, Leiden University Medical Center, Leiden; The Netherlands, and Research Laboratories, "Tharming Group NV, Leiden, The Netherlands
\end{abstract} \\ and the Department of Emergency and Organ Transplantation,
}

Ischemia-reperfusion injury is the major cause of delayed graft function in transplanted kidneys, an early event significantly affecting long-term graft function and survival. Several studies in rodents suggest that the alternative pathway of the complement system plays a pivotal role in renal ischemia-reperfusion injury. However, limited information is currently available from humans and larger animals. Here we demonstrated that 30 minutes of ischemia resulted in the induction of $\mathrm{C} 4 \mathrm{~d} / \mathrm{C} 1 \mathrm{q}, \mathrm{C} 4 \mathrm{~d} / \mathrm{MLB}$, and MBL/MASP-2 deposits in a swine model of ischemia-reperfusion injury. The infusion of C1-inhibitor led to a significant reduction in peritubular capillary and glomerular $\mathrm{C} 4 \mathrm{~d}$ and C5b-9 deposition. Moreover, complement-inhibiting treatment significantly reduced the numbers of infiltrating $\mathrm{CD}_{163}{ }^{+}, \mathrm{SWC}_{3} \mathrm{a}^{+}, \mathrm{CD} 4 \mathrm{a}^{+}$, and $\mathrm{CD}^{+} \mathrm{a}^{+}$ cells. C1-inhibitor administration led to significant inhibition of tubular damage and tubular epithelial cells apoptosis. Interestingly, we report that focal C4d-deposition colocalizes with $\mathrm{C1q}$ and $\mathrm{MBL}$ at the peritubular and glomerular capillary levels also in patients with delayed graft function. In conclusion, we demonstrated the activation and a pathogenic role of classical and lectin pathways of complement in a swine model of ischemia-reperfusion-induced renal damage. Therefore, inhibition of these two pathways might represent a novel therapeutic approach in the prevention of delayed graft function in kidney transplant recipients. (Am J Pathol 2010, 176:1648-1659; DOI: 10.2353/ajpath.2010.090276)

Delayed graft function (DGF) is the primary early posttransplant complication of kidney recipients. ${ }^{1}$ This event, histologically characterized by the presence of acute tubular necrosis, has been reported to occur in $25 \%$ to $30 \%$ of renal transplants. ${ }^{1}$ DGF is commonly associated with a significantly longer hospital stay and an increase in peritransplant morbidity. Moreover, this early complication seems to result in a marked reduction in long-term graft survival. ${ }^{2}$ Indeed, DGF is associated with an increased rate of acute rejection and a suboptimal renal function at 1-year post-transplantation. ${ }^{1-3}$

Ischemia followed by reperfusion plays a pivotal role in the pathogenesis of early graft damage. ${ }^{1}$ Ischemiareperfusion injury is characterized by two main features at the renal level: apoptosis of tubular cells and interstitial inflammation. Although many steps in the cascade of events leading to ischemia-reperfusion injury are unclear, the most promising potential mechanisms include recruitment and activation of inflammatory cells and local priming of the complement cascade. ${ }^{4-6}$

The complement system is a major constituent of the innate immune system, participating in the pathogenesis

\footnotetext{
Supported by University of Bari and Regione Puglia (PhD in Biotechnology applied to Organ and Tissue Transplantation, R.M. and C.D.) and an unrestricted research grant from Pharming Group NV, Leiden, The Netherlands.

G.C. and R.M. equally contributed to the present study.

Accepted for publication December 4, 2009.

Pharming Group NV has a financial interest in the use of recombinant human $\mathrm{C} 1$ inhibitor ( $\mathrm{rhC} 1 \mathrm{NH}$ ) in preventing delayed graft function after solid organ transplantation.

Address reprint requests to Giuseppe Castellano, M.D., Ph.D.; Renal, Dialysis, and Transplantation Unit; Department of Emergency and Organ Transplantation; University of Bari, Policlinico, Piazza Giulio Cesare 11, 70124 Bari, Italy. E-mail: g.castellano@nephro.uniba.it.
} 
of tissue damage through sequential activation of different proteases. The priming of this proteolytic cascade may occur by classical, alternative, and lectin-mediated activation pathways, and generates several pro-inflammatory mediators. ${ }^{6,7}$ Studies in animal models have shown complement activation in the kidney after ischemiareperfusion, leading to the generation of several mediators of inflammation, such as C3a, C5a, and C5b-9. ${ }^{4}$ Mice deficient in complement components such as $\mathrm{C} 6$ show very limited damage after renal ischemia-reperfusion injury. ${ }^{8}$ Moreover, the use of anti-factor B or C5a-receptor antagonists has been shown to reduce renal damage due to ischemia-reperfusion. ${ }^{9,10}$ Therefore, prevention of complement activation is currently considered one of the best therapeutic targets to prevent or limit ischemia-reperfusion-induced renal damage.$^{5,6,11} \mathrm{C} 1$-inhibitor $(\mathrm{C} 1 \mathrm{NH})$ is a potent inhibitor of proteases of the classical and lectin complement pathways $(\mathrm{C} 1 \mathrm{r}, \mathrm{C} 1 \mathrm{~s}$, and MASP2). ${ }^{6,11,12}$ Animal studies show that $\mathrm{C} 1 \mathrm{INH}$ can protect liver, intestine, heart, and brain tissue from ischemiareperfusion damage. ${ }^{13}$ There are no published data on the effect of $\mathrm{C} 1 \mathrm{INH}$ on ischemia-reperfusion-induced renal damage, since most of the existing evidence suggests that in this setting complement activation is mainly induced through the alternative pathway. ${ }^{5,14}$ However, all data reported in the literature are from murine models, and no information is currently available from larger animals and/or human subjects.

The aim of the present study was to investigate the pattern of complement activation in patients with DGF and to test the efficacy of a recombinant form of human $\mathrm{C} 1 \mathrm{INH}(\mathrm{rhC} 1 \mathrm{NH})$ in preventing renal damage in a swine model of warm ischemia-reperfusion injury.

\section{Materials and Methods}

\section{Renal Ischemia-Reperfusion Injury Model}

After approval by the ethical committee of the Ministry of Health, ten 4-month-old female Large White pigs weighting $20 \mathrm{~kg}$ underwent experimental open surgical procedure under general anesthesia. The animals were fasted for 24 hours before induction of anesthesia. The electrocardiogram, heart rate, hemoglobin saturation of oxygen, respiratory gas composition, respiratory rate, tidal volume, airway pressure, systolic arterial blood pressure, and central venous pressure were continuously monitored and automatically recorded (Ohmeda Modulus CD; Datex Ohmeda, Helsinki, Finland).

The left renal artery and vein were isolated and a vessel loop was positioned around the renal artery with a right angle clamp. A renal biopsy was performed before ischemia (TO). Then, the ischemic phase was induced (30 minutes) by pulling on the vessel loop. Five minutes before the end of the ischemia time, $r \mathrm{rC} 1 \mathrm{INH}$, isolated from the milk of transgenic rabbits (Pharming), was diluted in saline solution and was injected in the ear vein of five animals ( $500 \mathrm{U} / \mathrm{kg}$ ); in another group of five animals an equal volume of vehicle was infused at the same time point (control group). Multiple biopsies were then per- formed at 15, 30, and 60 minutes after reperfusion; animals where sacrificed 24 hours after the surgical procedure. A portion of each biopsy specimen was immediately snapfrozen in optimal cutting temperature (Tissuetek) medium and stored in liquid nitrogen. Another portion was fixed in buffered formalin (4\%) for 12 hours and embedded in paraffin using standard procedures.

\section{In Vitro and ex Vivo Effects of rhC1/NH on Swine Complement System}

Sera from three healthy pigs were incubated with $\mathrm{rhC} 1 \mathrm{INH}$ at different concentration $(1,2,3 \mathrm{U} / \mathrm{ml})$ or vehicle for 30 minutes at $37^{\circ} \mathrm{C}$. The inhibition of complement functional activity in classical, alternative, and lectin pathways was assessed using a commercially available enzyme immunoassay kit (Wielisa, Wieslab, Lund, Sweden). ${ }^{15}$ Briefly, the assay used a specific coating for each pathway so that only activation of that particular pathway occurs up to C9 (human IgM for the classical pathway, LPS for the alternative pathway and mannan for MBL pathway). Complement activity via each pathway was detected using a specific monoclonal antibody against the C5b-9 complex.

In addition, blood samples were collected from three pigs, weighting 20 to $38 \mathrm{~kg}$, at different times $(0,15,60$, and 240 minutes) after the administration of rhC1INH $(500 \mathrm{U} / \mathrm{kg})$ to assess complement activation (Wielisa).

\section{Patients}

Forty-one consecutive primary kidney transplant patients receiving kidneys from deceased donors and experiencing DGF were enrolled in this observational study. All patients signed an informed consent form agreeing to participate in the study. The presence of DGF was defined as the need for dialysis in the first week after transplantation. All patients included in the study were given $500 \mathrm{mg}$ of methylprednisolone intraoperatively, followed by $250 \mathrm{mg}$ of prednisone daily, with the dose tapered to $25 \mathrm{mg}$ by day $8 ; 20 \mathrm{mg}$ of a chimeric monoclonal antiCD25 antibody (Simulect, Novartis) intravenously on day 0 and day 4; mycophenolate mofetil (Cell-Cept, Roche) $1000 \mathrm{mg}$ b.i.d and either cyclosporine A (Neoral, Novartis, C2 levels 800 to $1200 \mathrm{ng} / \mathrm{ml}$ ) or tacrolimus (Prograf, Astellas, through levels 8 to $12 \mathrm{ng} / \mathrm{ml}$ ). According to our standard clinical protocol, a wedge biopsy before transplantation was performed on all deceased donor kidneys. A second graft biopsy was performed 7 to 15 days (mean 10.2 days) after transplantation in all patients with DGF. All patients with pretransplant panel reactive antibodies (PRA, Luminex, One Lambda, Montpellier France) > $0 \%$, or historical evidence of neoplasia, active systemic infection, or biopsy-proven acute rejection were excluded from the study. As control group, we used 10 kidney graft recipients that underwent renal biopsy within 15 days from transplantation for calcineuirin inhibitors toxicity. In DGF patients the graft biopsy revealed a diffuse acute tubular necrosis with no evidence of acute rejection including borderline changes and/or diffuse 
peritubular capillary deposition of C4d. At the same time no patient presented with an increase of PRA. The study was performed according to the principles of the Declaration of Helsinki and was approved by our Ethics Committee.

\section{Microscopy Study}

Paraffin-embedded renal specimens from the animal model and from renal biopsies were used for conventional histological staining (H\&E, periodic acid-Schiff). Tubulointerstitial and glomerular lesions were evaluated using a qualitative analysis by two observers (M.R., G.G.) who were unaware of the origin of the slides.

\section{Antibodies}

The primary antibodies used in this study recognized the following antigens: CD8a (76-2-11, BD Biosciences, San Jose, CA); CD4a (MIL17, AbD Serotec, Oxford, UK); CD163 (monocytes/macrophages, US biological, Swampscott, MA); SWC3a (dendritic cells, ${ }^{16} 74-22-15 A$, BD Biosciences); caspase-3 (Novus Biologicals, Inc, Littleton, CO); C1q (R9/2, AbD Serotec); MBL (3E7, Hycult biotechnology b.v., Uden, the Netherlands); C4d (Biomedica Gruppe, Wien, Austria); Factor B (Novus Biologicals); C9 neo antigen (aE11, Dako, Glostrup, Denmark); MASP-2 (N-20, Santa Cruz Biotechnology, Santa Cruz, CA); and C3c (Dako Cytomation, Glostrup, Denmark). The cross reactivity was validated pre-incubating the specific antibodies, before their use, with human peptides used to raise them. The pre-incubation completely abolished the specific staining on swine tissue.

\section{Immunohistochemical Analysis}

\section{C4d, Caspase3}

Two $\mu \mathrm{m}$-thick sections of human and pig paraffinembedded renal tissue were rehydrated by a series of xylene and graded alcohol washes. After antigen retrieval, the sections were blocked with bovine serum albumin $2 \%$ for 1 hour at room temperature. The sections were incubated with the primary antibodies (anti-C4d or anti-caspase3) and detected by the Dako EnVision G/2 System (Dako). The sections were counterstained with Mayer's hematoxylin and mounted with glycerol. Negative controls were obtained incubating serial sections with the blocking solution and irrelevant antibody.

\section{CD163, CD4a, CD8a}

Cryostat sections ( $4 \mu \mathrm{m}$-thick) of frozen pig kidneys were stained for infiltrating cells markers. Slides were prepared and incubated with specific antibodies. Endogenous peroxidase activity was blocked by $3 \% \mathrm{H}_{2} \mathrm{O}_{2}$ for 7 minutes. The tissue samples were then incubated with Dako Real EnVision Detection System (Dako). The reaction was visualized by a brown precipitate, counterstained with Mayers hematoxylin (blue) and mounted with glycerol (DakoCytomation, Carpintera, CA). Negative controls were obtained incubating serial sections with the blocking solution and then control irrelevant antibody.

\section{Staining Scoring}

The number of $\mathrm{C} 4 \mathrm{~d}+$ peri-tubular capillaries and the number of CD163+, CD4a+, and CD8a+ infiltrating cells were evaluated in at least 10 high power $(\times 630)$ fields (hpf)/section by two independent observers blinded to the origin of the slides. The final counts were the mean of the two measures. In no case interobserver variability was higher than 20\%. Specific C4d immunostaining at the glomerular level was quantified using Adobe Photoshop software and expressed as pixel/glomeruli.

\section{Tissue Immunofluorescence and Confocal Laser Scanning Microscopy}

Human and pig sections were double-stained for $\mathrm{C} 1 \mathrm{q} /$ C4d, MBL/C4d, and MASP2/MBL. The slides were incubated with protein block serum-free (Dako) for 10 minutes and $2 \%$ bovine serum albumin for 1 hour at room temperature. Slides were then incubated for 1 hour at room temperature with the specific antibodies. Slides were then incubated with the appropriate secondary antibodies (Alexa Flour 488 goat anti-rabbit and 555 anti-mouse, both from Molecular Probes, Eugene, OR). For Factor B, C5b-9, and SWC3a detection, slides were incubated with the specific antibody overnight at $4^{\circ} \mathrm{C}$. After three washes in PBS, slides were incubated with the appropriate secondary antibody (Molecular Probes). All sections were counterstained with TO-PRO-3 (Molecular Probes). Negative controls were prepared with irrelevant antibody. The sections were analyzed using the Leica TCS SP2 (Leica, Wetzlar, Germany) confocal laser-scanning microscope. The number of SWC3a+ cells was measured in at least 10 high power $(\times 630)$ fields/section by two independent observers blinded to the origin of the slides. The final counts were the mean of the two measures. In no case interobserver was variability higher than $20 \%$.

\section{Statistical Analysis}

Data are expressed as the mean \pm SD. Difference between groups was analyzed by paired $t$-test analysis. A $P$ value $<0.05$ was considered statistically significant.

\section{Results}

\section{Activation of Classical, Lectin, and Alternative Pathways in a Swine Model of Ischemia-Reperfusion Injury}

We first investigated the mechanism of complement cascade activation in the swine model of warm ischemiareperfusion-induced renal injury. The terminal complement complex, C5b-9, was barely detectable in the basal 

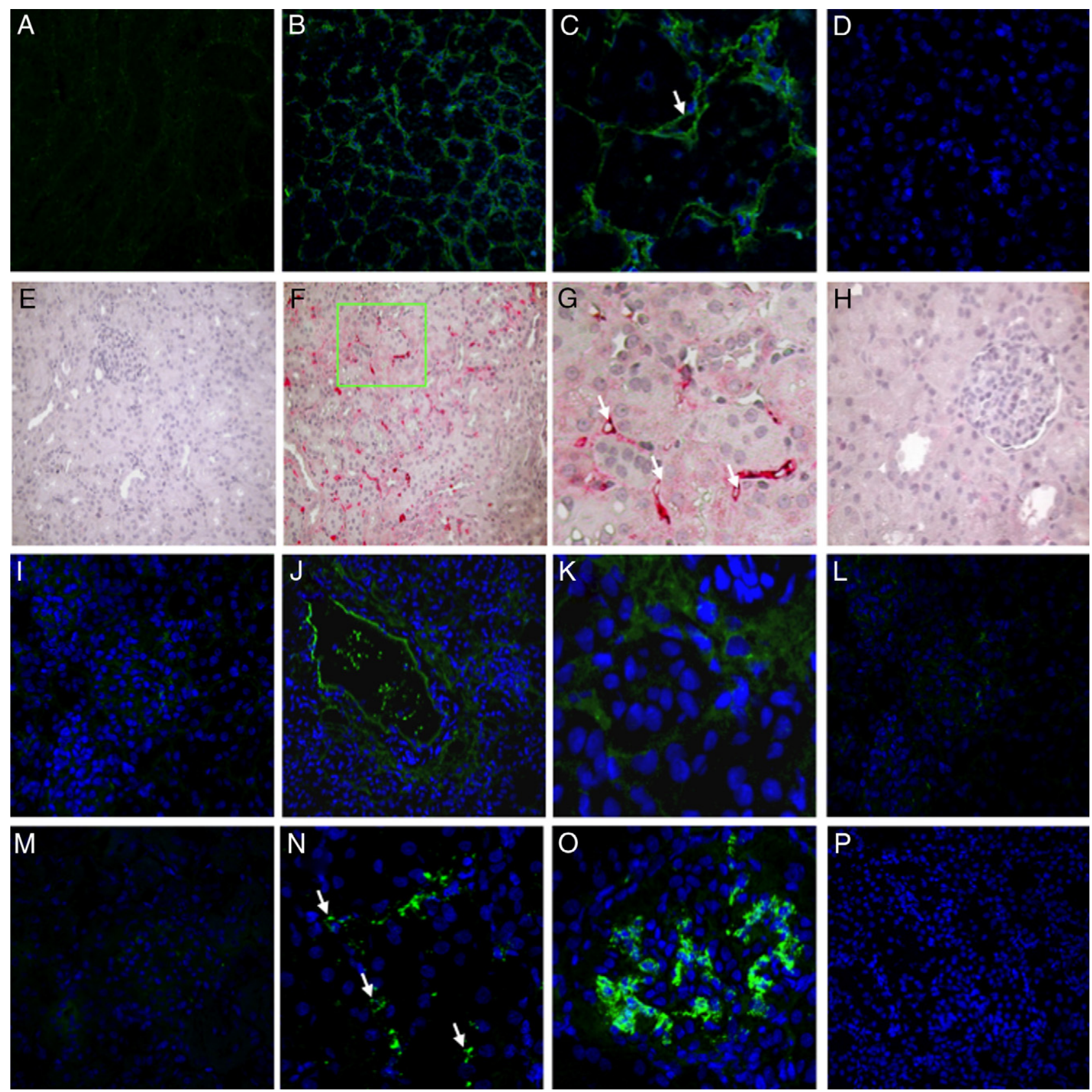

Figure 1. Classical, alternative, and lectin pathway activation in a pig model of ischemia-reperfusion injury. Frozen pig kidney sections were examined for expression of the membrane attack complex (C5b-9) by immunofluorescence and confocal analysis (A-D). C5b-9-deposition, completely absent before ischemia (A), was significantly up-regulated 30 minutes after reperfusion (B), in particular at the peritubular and capillary level (C, arrow) and disappeared 24 hours after reperfusion (D). C4d deposition was evaluated by immunohistochemistry on paraffin-embedded kidney sections (E-H). Specific C4d staining was not observed at T0 (E). Thirty min of reperfusion induced a diffuse deposition of C4d (F) with a specific localization at the peritubular capillaries (G, arrows) that disappeared at 24 hours $(\mathbf{H})$. Factor B deposition was investigated by immunofluorescence and confocal analysis $(\mathbf{I}-\mathbf{L})$. Factor B deposition, completely absent before ischemia (I), was significantly up-regulated 30 minutes after reperfusion (J), particularly at the interstitial and tubular level (K), and disappeared 24 hours after reperfusion (L). Complement C3 deposition was investigated by immunofluorescence and confocal analysis ( $\mathbf{M}-\mathbf{P})$. Complement C3 deposition, absent before ischemia ( $\mathbf{M})$, was significantly increased 30 minutes after reperfusion $(\mathbf{N}-\mathbf{O} ; \mathbf{N}$, peritubular capillaries indicated by arrows), and disappeared 24 hours after reperfusion $(\mathbf{P})$. In confocal microscopy images nuclei were stained with TO-PRO-3 (blue).

biopsies (Figure 1A). Thirty minutes of ischemia caused a diffuse deposition of C5b-9 at 30' of reperfusion (Figure $1, \mathrm{~B}$ and $\mathrm{C}$ ), which disappeared after 24 hours (Figure 1D). The complement terminal complex was localized at the peritubular level (Figure 1B) as well as within the peritubular capillaries along the endothelial cell layer (Figure 1C, arrow).
Subsequently, we investigated the presence of $\mathrm{C} 4 \mathrm{~d}$ in kidney biopsies before and after reperfusion. As shown in Figure $1 \mathrm{E}$, before the induction of ischemia, $\mathrm{C} 4 \mathrm{~d}$ deposits were undetectable in renal biopsies, whereas after 30 minutes of reperfusion, we observed a significant deposition of $\mathrm{C} 4 \mathrm{~d}$ both at tubulointerstitial (Figure 1, F and G) and glomerular (data not shown) levels. In both cases 

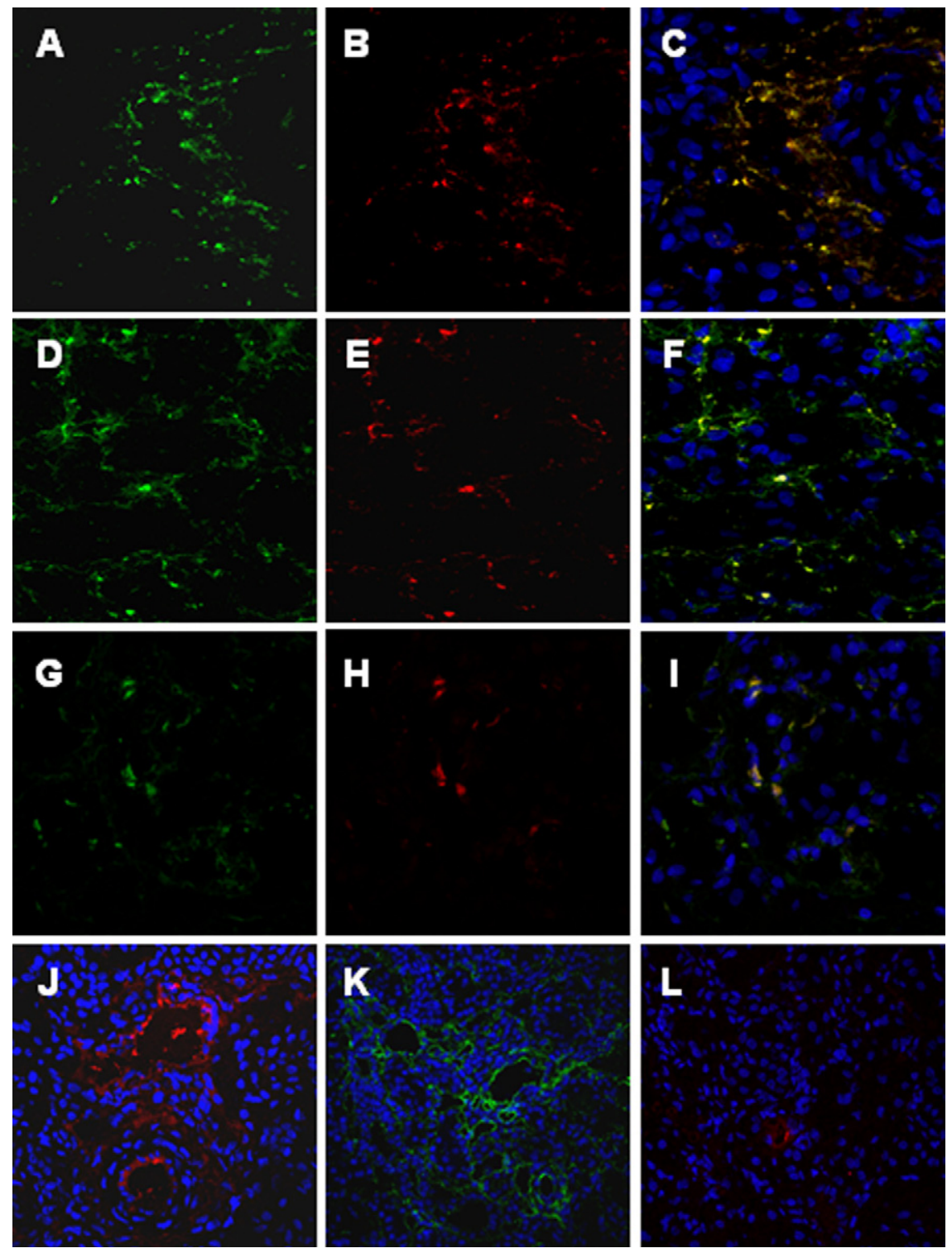

Figure 2. C4d deposition in the swine model of ischemia-reperfusion-induced renal injury is due to both classical and lectin pathways activation. Co-localization of $\mathrm{C} 4 \mathrm{~d}$ with $\mathrm{C} 1 \mathrm{q}(\mathbf{A}-\mathbf{C})$, MBL $(\mathbf{D}-\mathbf{F})$, and $\mathrm{MBL} / \mathrm{MASP}-2(\mathbf{G}-\mathbf{I})$ was investigated on frozen kidney sections by immunofluorescence/confocal microscopy. A: Interstitial and capillary deposition of C4d (green), (B) interstitial deposition of $\mathrm{C} 1 \mathrm{q}$ (red); (C) co-deposition of C1q-C4d at interstitial level (merge) D: Interstitial and capillary deposition of C4d (green), (E) interstitial and capillary deposition of MBL (red); (F) co-deposition of MBL-C4d at interstitial and capillary level (merge). The same pattern of co-deposition was also observed for MASP-2/MBL (G-I). The complement cascade was predominantly activated by the lectin and alternative pathways at 15 minutes of reperfusion. MBL, factor B and C1q deposits were investigated by immunofluorescence/confocal microscopy. The extent of MBL (J) and factor B (K) deposition was significantly higher than the one observed for C1q (L). Nuclei were stained with TO-PRO-3 (blue)
C4d deposits were localized at the endothelial cells surface (Figure 1G, arrows). As described for C5b-9, the deposition of $\mathrm{C} 4 \mathrm{~d}$ was markedly reduced at 24 hour (Figure $1 \mathrm{H}$ ). Moreover, we confirmed the activation of the alternative pathway in this setting. Indeed, factor B deposition, completely absent in the kidney before ischemia (Figure 1I), was significantly increased after 30 minutes of reperfusion (Figure $1, \mathrm{~J}$ and $\mathrm{K}$ ). Factor $\mathrm{B}$ was mainly present at the interstitial and tubular level (Figure 1J), as previously described. The alternative pathway was also transiently activated in this model of renal ischemiareperfusion injury, since factor $B$ deposits were virtually absent after 24 hours of reperfusion (Figure 1L). Finally, the C3c deposits appeared with the same time and spatial pattern of the previously described complement factors (Figure 1, M-P). C3c was localized on peritubular capillaries (Figure $1 \mathrm{~N}$, arrows), and on glomerular endothelial cells (Figure 10).

Since C4 deposition could be due to either classical or lectin pathway activation, we then investigated whether
C4d deposits in our swine model of ischemia/reperfusion colocalized with either $\mathrm{C} 1 \mathrm{q}$ or $\mathrm{MBL}$. We observed the co-deposition of $\mathrm{C} 4 \mathrm{~d}$ with both $\mathrm{C} 1 \mathrm{q}$ (Figure 2, $\mathrm{A}-\mathrm{C}$ ) and MBL (Figure 2, D-F). To further confirm the activation of the lectin pathway we studied also the deposition of MASP-2. As shown in Figure 2, G-I, MASP-2 colocalized with MBL.

To clarify which of the three complement pathways was primarily activated in our experimental model, we investigated $\mathrm{C} 1 \mathrm{q}, \mathrm{MBL}$, and factor B deposition 15 minutes after reperfusion. The extent and diffusion of $\mathrm{MBL}$ (Figure 2J) and factor B (Figure 2K) deposits were significantly more pronounced then $\mathrm{C} 1 \mathrm{q}$ deposition (Figure $2 \mathrm{~L}$ ), suggesting a predominant role of the lectin and alternative pathways in this setting.

\section{rhC1INH Treatment and C4d Deposition}

On the basis of our data in the swine model of ischemiareperfusion-induced renal injury, we hypothesized that 

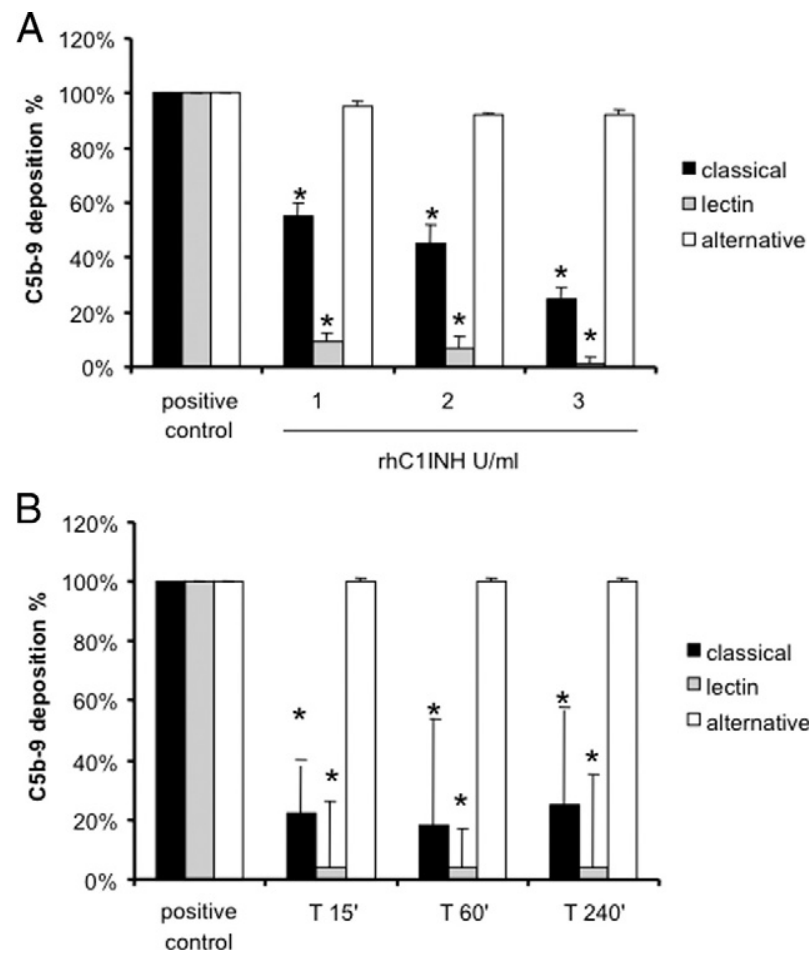

Figure 3. Assessment of functional activity of classical, alternative, and lectin pathways in pig sera. A: Increasing concentrations of rhC1INH were incubated with sera from healthy pigs to evaluate the capacity to inhibit the classical and lectin pathways (Wielisa, Wieslab). ${ }^{*} P<0.05$ versus positive control (pig sera with vehicle). B: Three healthy pigs received $500 \mathrm{U} / \mathrm{kg}$ of rhC1INH; then, serum samples were collected at different time points and evaluated for complement activation by Wielisa. ${ }^{*} P<0.05$ versus positive control.

rhC1INH, a specific inhibitor of both classical and lectin pathways, might reduce the activation of the complement cascade in this setting. We first tested in vitro the ability of rhC1INH to inhibit the classical and lectin pathways in pig sera. Increasing concentrations of rhC1INH were able to reduce more than $50 \%$ of $\mathrm{C} 5 \mathrm{~b}-9$ generation due to the activation of the classical pathway in vitro (Figure $3 A$ ). Interestingly, inhibition of the lectin pathway reached $100 \%$ at the concentration of $3 \mathrm{U} / \mathrm{ml}$ (Figure 3A). In addition, we tested ex vivo the ability of the rhC1INH to modulate the lectin and classical pathway of complement activation. We infused $500 \mathrm{U} / \mathrm{kg}$ i.v. in three animals and collected serum samples at different time points. The drug was able to significantly reduce both lectin and classical pathway activation up to 240 minutes after infusion (Figure 3B).

We then moved to the experimental model and observed that the animals receiving rhC1INH i.v. 5 minutes before reperfusion presented a clear reduction in $\mathrm{C} 4 \mathrm{~d}$ deposition at the tubulointerstitial and glomerular (Figure 4, A-C) levels compared with control animals (Figure 4, D-F). Quantification of C4d deposit at tubulointerstitial and glomerular levels demonstrated a significant difference between treated and untreated animals at multiple postreperfusion time points (Figure 4, G and $\mathrm{H}$, respectively). In addition, we also observed a marked reduction in the deposition of C5b-9 (Figure 5, A-C) and MASP2 (Figure 5, D-F) in rhC1INH-treated animals.
rhC1INH Treatment and Infiltrating Inflammatory Cells

Next, we investigated the ability of rhC1INH to reduce the recruitment of infiltrating inflammatory cells, one of the hallmarks of ischemia-reperfusion injury, by inhibiting complement activation. Control pigs showed significant recruitment of infiltrating $\mathrm{CD} 163+$ monocyte/macrophages (Figure 6, A and B), whereas rhC1INH-treated pigs showed a significant decrease of CD163+ cells throughout the observation period (Figure 6, C and D). In addition, we investigated the presence of dendritic cells using a specific polyclonal antibody against SWC3a+. As previously reported, ${ }^{16}$ infiltrating dendritic cells were significantly increased after reperfusion in the vehicletreated animals (Figure 6, E and F). Interestingly, rhC1INH-treated pigs showed a significant reduction in infiltrating SWC3a+ cells throughout the observation period (Figure $6, \mathrm{G}$ and $\mathrm{H}$ ).

Finally, we investigated whether the recruitment of $T$ lymphocytes might also be influenced by rhC1INH therapy. As shown in Figure $7 \mathrm{~A}$, rare $\mathrm{CD} 4^{+} \mathrm{T}$ cells were present within the tubulointerstitial area before the induction of ischemia-reperfusion. After 24 hours of reperfusion (Figure 7B), there was a major influx of these cells. The recruitment of $\mathrm{CD} 4^{+} \mathrm{T}$ cells during the 24 hours was greatly reduced in rhC1INHtreated animals (Figure 7, C and D).

CD8 + T lymphocytes were also absent in the normal kidney (Figure 7E) and we observed a significant tubulointerstitial influx of these cells, most notable 24 hours after reperfusion, in the vehicle-treated animals (Figure $7 \mathrm{~F})$. In rhC1INH-treated animals this increase was not observed (Figure 7, $\mathrm{G}$ and $\mathrm{H}$ ).

\section{rhC1INH Treatment and Tubular Damage}

Together with the recruitment of infiltrating inflammatory cells, the other main feature of ischemia-reperfusion injury is tubular epithelial cell damage. On routine histological evaluation, untreated animals developed tubular vacuolization, loss of brush border, and lumen dilatation after 60 minutes of reperfusion that increased in severity up to 24 hours postreperfusion (Figure 8 , $A-C)$. These changes were markedly reduced in rhC1INH-treated animals (Figure 8, D-F). We then examined tubular cell apoptosis using caspase-3 expression as a specific marker. Caspase-3+ cells, rarely present within tubular sections at baseline (Figure 8G), were dramatically increased 60 minutes and 24 hours after reperfusion (Figure $8, \mathrm{H}$ and $\mathrm{I}$, respectively). Interestingly, this phenomenon was completely abolished in rhC1INH-treated animals (Figure 8, J, K, and L). Quantification of caspase-3+ cells demonstrated that the difference between the two groups was significant at all of the time points evaluated (Figure $8 \mathrm{M})$. 

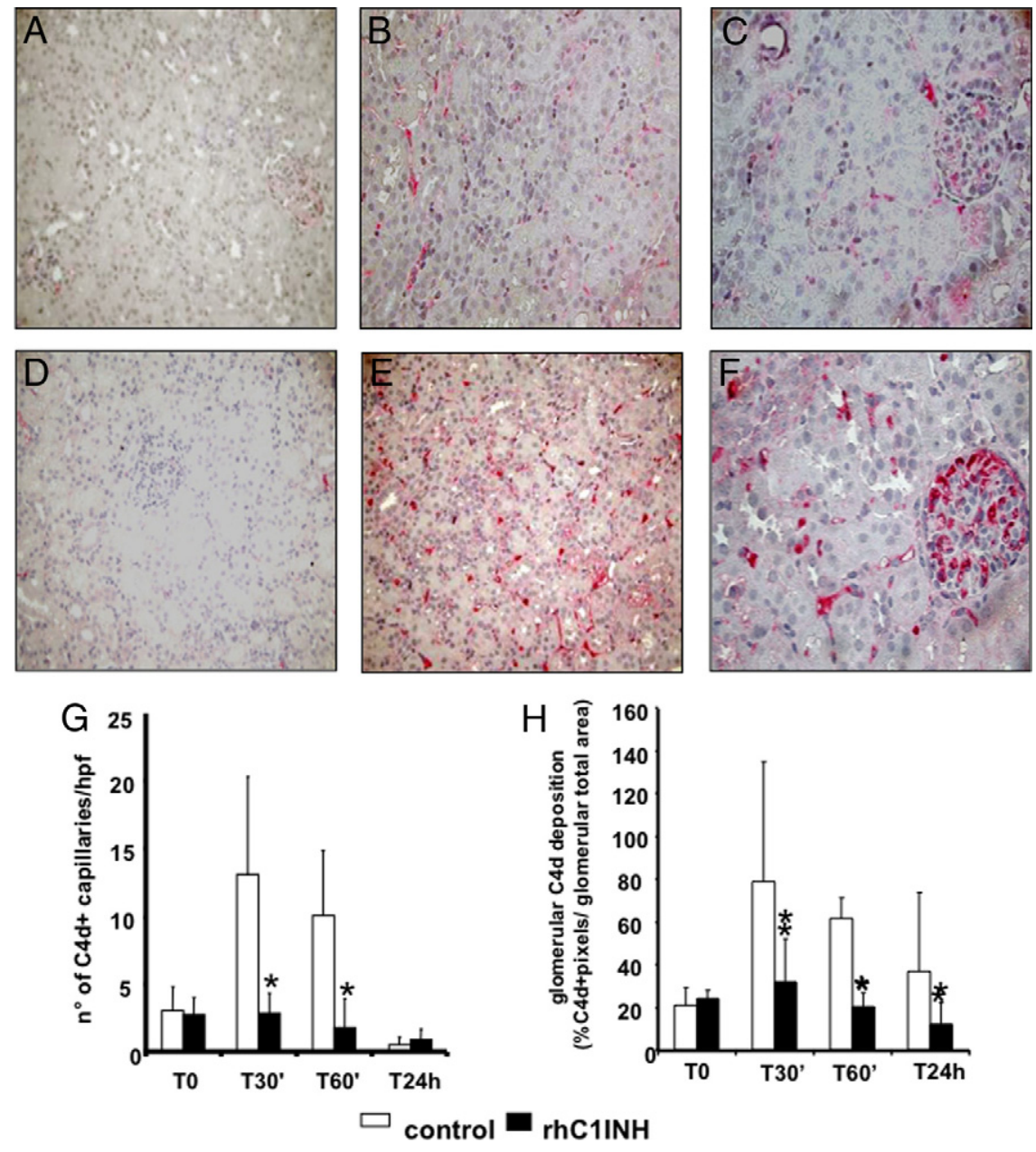

Figure 4. Inhibition of C4d deposition by rhC1INH treatment in a swine model of ischemia-reperfusion-induced renal injury. C4d deposits were evaluated by immunohistochemistry on paraffin-embedded kidney sections from animals treated either with rhC1INH $(500 \mathrm{UI} / \mathrm{kg}$, $\mathbf{A}-\mathbf{C})$ or vehicle (D-F). The C4d deposits, absent before ischemia induction $(\mathbf{A}, \mathbf{D})$, remained significantly lower in the treated group both at the tubulointerstitial (B) and glomerular (C) level compared with untreated animals (tubulointerstitial: E; glomerular: F) Original magnification $\times 400 x$. G: Quantification of peritubular capillary $\mathrm{C} 4 \mathrm{~d}+$ at the different times of reperfusion in treated $(n=5)$ and control animals $(n=$ 5). Results are expressed as the mean $\pm \mathrm{SD}$ of $\mathrm{C} 4 \mathrm{~d}+$ capillary/high power field (hpf). ${ }^{*} P<0.05$ versus time-matched vehicle-treated animals. H: Quantification of glomeruli C4d+. Result are expressed as the mean $\pm \mathrm{SD}$ of glomerul $\mathrm{C} 4 \mathrm{~d}+.{ }^{*} P<0.05$ vs. time-matched vehicle-treated animals.

\section{Analysis of Complement Activation in Patients with DGF}

Biopsy specimens from 41 transplant recipients with DGF were analyzed to detect fragments derived from activa- tion of the complement system. Forty percentage of DGF patients showed focal C4d deposits in peritubular capillary, 34\% showed deposition at the tubulointerstitial level, and $41 \%$ showed deposition at the glomerular capillary level. Interestingly, none of the patients with $\mathrm{C} 4 \mathrm{~d}$ deposits
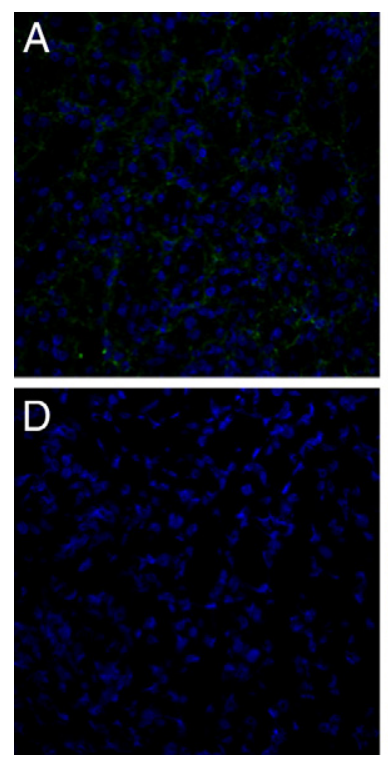
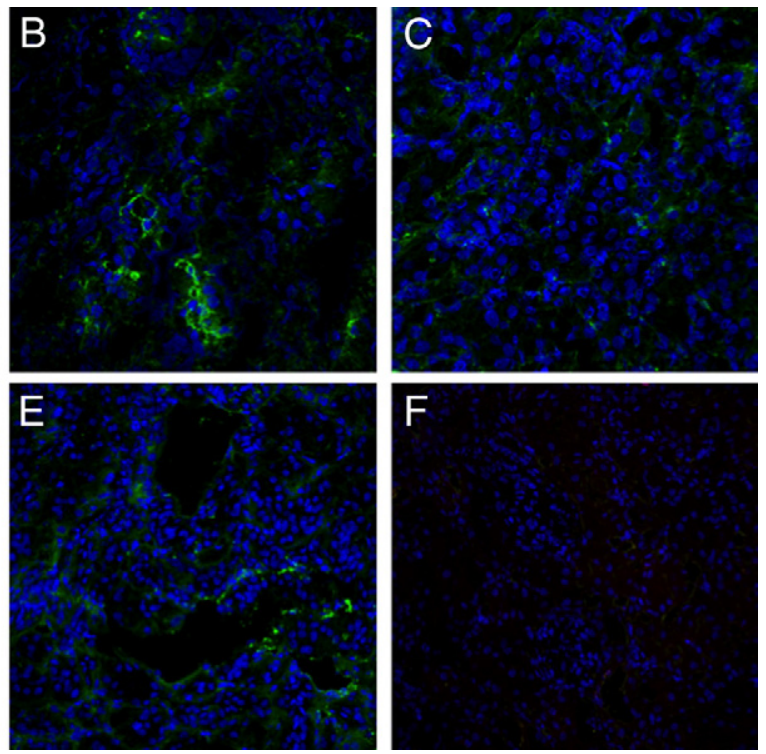

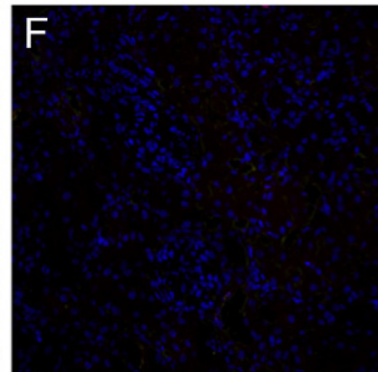

Figure 5. Inhibition of $\mathrm{C} 5 \mathrm{~b}-9(\mathbf{A}-\mathbf{C})$ and MASP-2 (D-F) deposition by rhC1INH treatment in a swine model of ischemia-reperfusion-induced renal injury. C5b-9 and MASP-2 deposits were investigated by confocal microscopy. Both were absent before ischemia ( $\mathbf{A}$ and $\mathbf{D}$, respectively) and were up-regulated 30 minutes after reperfusion (B and $\mathbf{E}$, respectively) in vehicle-treated animals. C1INH infusion caused a marked reduction in the deposition of both, C5b-9 (C) and MASP-2 (F). 

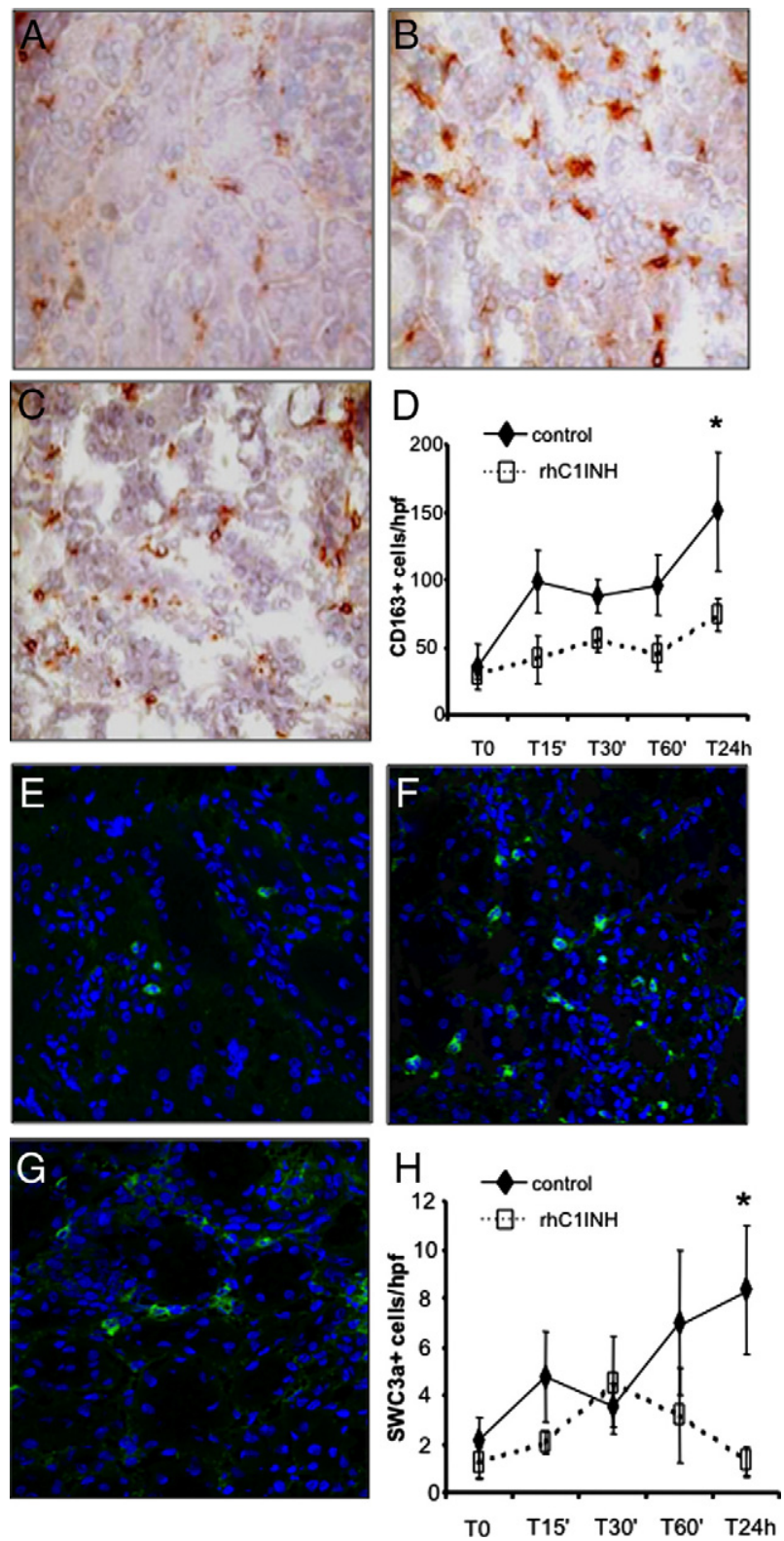

Figure 6. Modulation of monocyte and dendritic cell infiltration by rhC1INH treatment in a swine model of ischemia-reperfusion-induced renal injury. CD163 (a monocyte/macrophage marker) expression was evaluated in kidney tissue cryosection by immunohistochemistry. A low number of infiltrating CD163+ cells was observed before ischemia within the interstitial compartment (A). Twenty-four hours of reperfusion in duced a significant recruitment of CD163+ cells (B) in vehicle-treated animals, whereas rhC1INH administration caused a marked reduction in the number of infiltrating monocytes (C). D: Quantification of CD163+ cells at different time points after induction of ischemia-reperfusion. Results are expressed as mean \pm s.d of CD163+cells/high power field (hpf). ${ }^{*} P<0.05$ versus T0 and versus T24 hours of rhC1INH-treated animals. Original magnification $\times 400$. The protein expression of SWC3 (a marker of dendritic cells) was investigated by immunofluorescence/confocal microscopy. Very few infiltrating SWC3A+ cells were observed before ischemia within the interstitial compartment (E). Twenty-four hours of reperfusion induced a significant recruitment of SWC3A+ cells (F) in vehicle-treated animals, whereas rhC1INH infusion caused a marked reduction in the number of infiltrating dendritic cells $(\mathbf{G})$. TOPRO-3 (blue) was used to counterstain nuclei. Original magnification $\times 630$. H: Quantification of SWC3a+ cells during ischemia-reperfusion. Results are expressed as mean \pm s.d of SWC3A+ cells/high power field (hpf). ${ }^{*} P<0.05$ versus T0 and versus T24 hours of rhC1INH-treated animals.
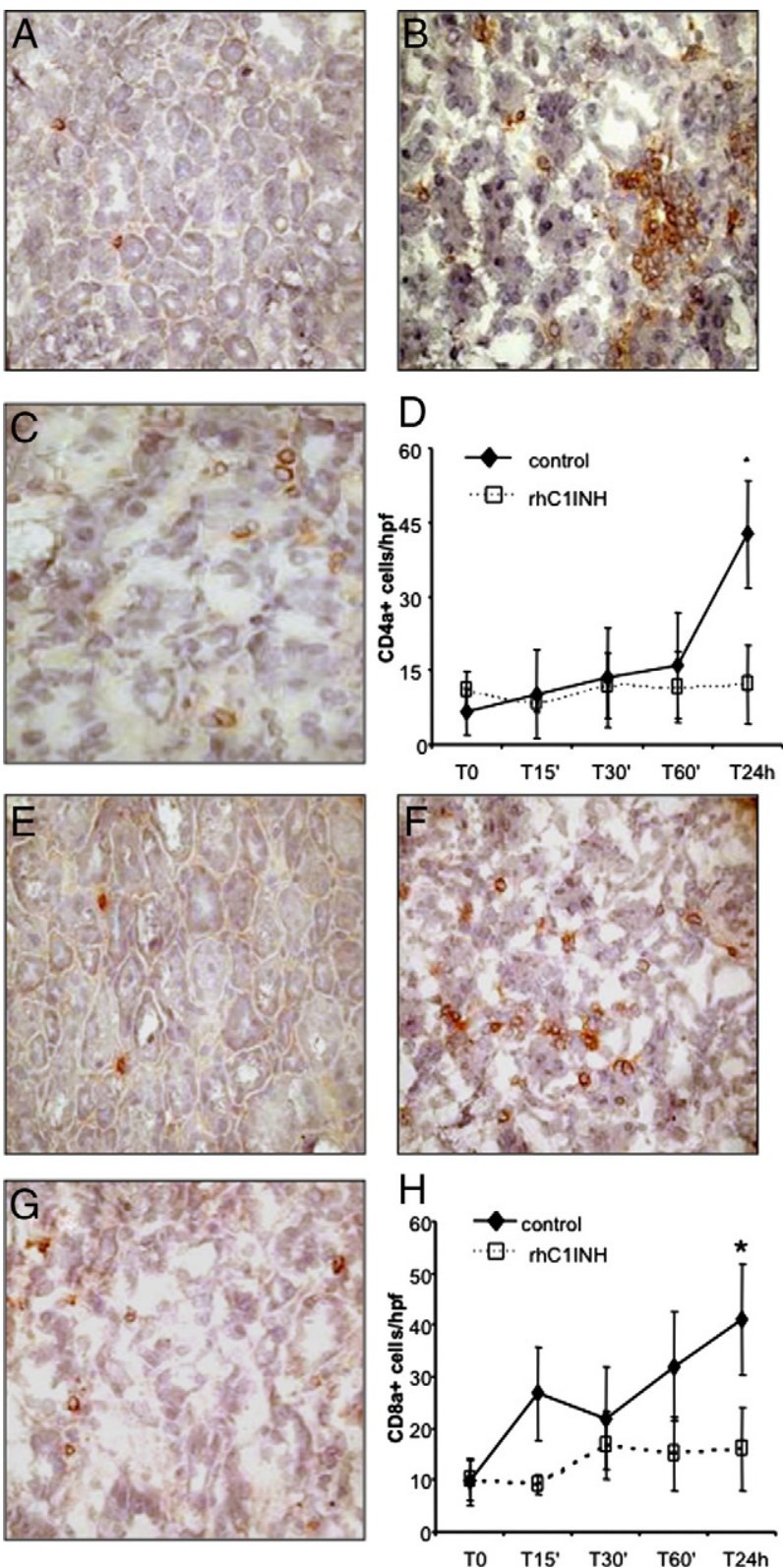

Figure 7. Modulation of lymphocytes infiltration by rhC1INH treatment in a swine model of ischemia-reperfusion-induced renal injury. CD4a expression was evaluated in kidney tissue cryosection by immunohistochemistry. Very few infiltrating CD4a+ cells were observed before ischemia within the interstitial compartment (A). Twenty-four hours of reperfusion induced a significant recruitment of CD4a + cells (B) in vehicle-treated animals, whereas rhC1INH administration caused a marked reduction in the number of infiltrating CD4a+ lymphocytes (C). D: Quantification of CD4a + cells at different time points after induction of ischemia-reperfusion. Results are expressed as the mean \pm s.d of CD $4 a+$ cells/high power field $(\mathrm{hpf}) .{ }^{*} P<0.05$ versus T0 and versus T24 hours of rhC1INH-treated animals. CD8a expression was investigated in kidney tissue cryosection by immunohistochemistry. Very few infiltrating CD8a+ cells were observed before ischemia within the interstitial compartment (E). Twenty-four hours of reperfusion induced the recruitment of $\mathrm{CD} 8 \mathrm{a}+$ cells $(\mathbf{F})$ in vehicletreated animals, whereas rhC1INH administration caused a marked reduction in the number of infiltrating CD8a + T cells $(\mathbf{G})$. H: Quantification of CD8a + cells at different time points after induction of ischemia-reperfusion. Nuclei were counterstained by hematoxylin. Original magnification $\times 400 .{ }^{*} P<.05$ versus T0 and versus T24 hours of rhC1INH-treated animals.

showed histological signs of acute rejection. As shown in Figure 9A, C4d deposits were present diffusely at the tubulointerstitial level and focally within the peritubular capillaries (Figure 9B). Moreover, the deposits 

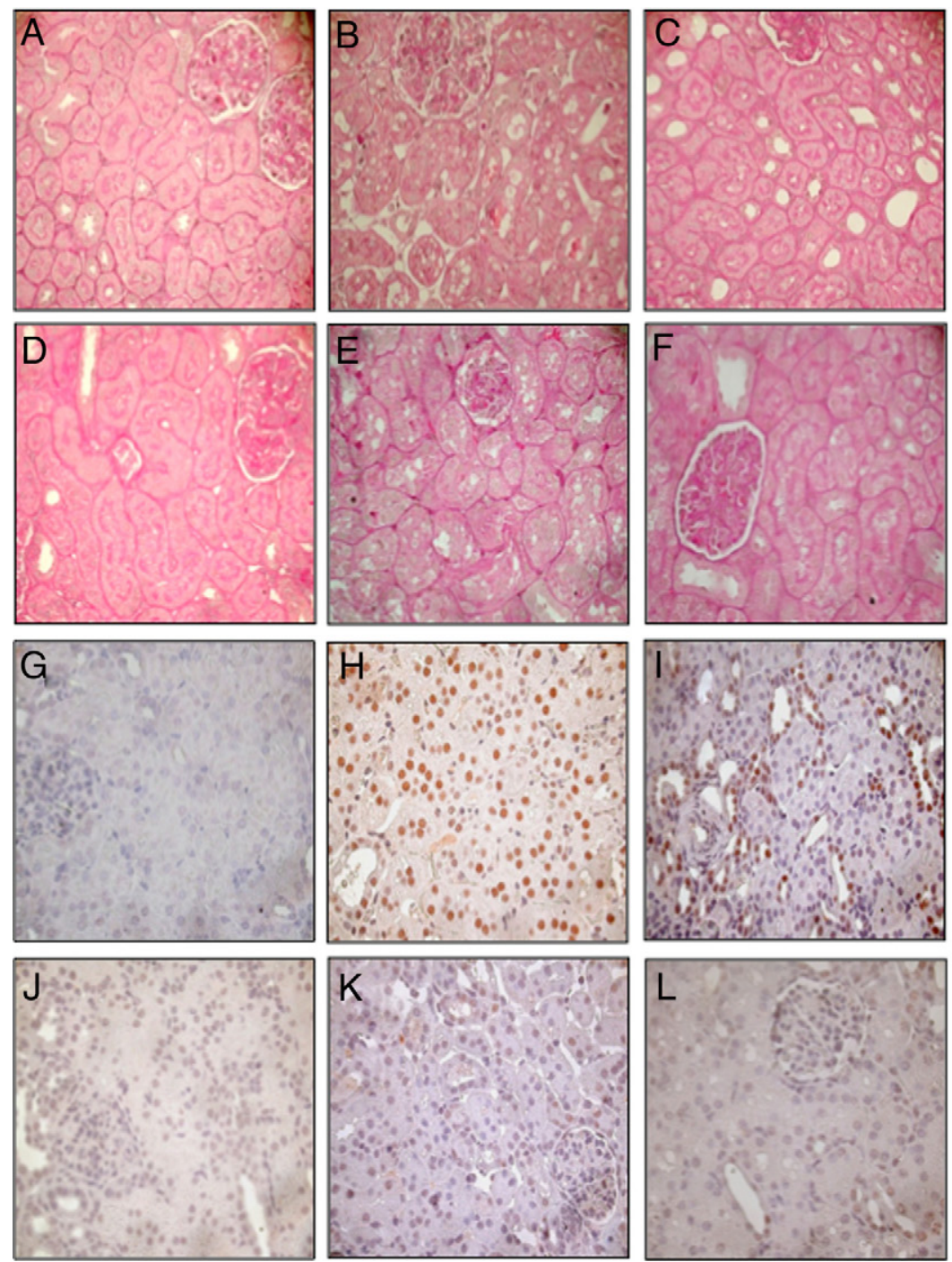

Figure 8. Modulation of tubulointerstitial damage and tubular cell apoptosis by rhC1INH treatment in a swine model of ischemia-reperfusion-induced renal injury. Compared with basal conditions (A) ischemia-reperfusion induced an evident vacuolization and an early cellular infiltrate associated with interstitial edema at the tubulointerstitial level (B: 60 minutes and C: 24 hours of reperfusion). Significantly less edema and tubular damage were present in pigs treated with rhC1INH (D: baseline, E: 60 minutes, and F: 24 hours of reperfusion) Nuclear protein expression of caspase-3 (a specific marker of late cell apoptosis) was evaluated by immunohistochemistry on paraffin-embedded tissue sections Very few caspase-3+ cells were observed before ischemia $(\mathbf{G})$. An increase in the number of apoptotic tubular cells was observed after 60 minutes $(\mathbf{H})$ and 24 hours $(\mathbf{I})$ of reperfusion in vehicle-treated animals. RhC1INH infusion caused a dramatic reduction in caspase- $3+$ cells at both time points (J: baseline, $\mathbf{K}: 60$ minutes, and $\mathbf{L}: 24$ hour). M: Quantification of caspase-3+ cells after renal ischemia-reperfusion injury. Results are expressed as mean $\pm \mathrm{SD}$ of caspase- $3+$ cells/high power fields (hpf). ${ }^{*} P<0.05$ versus vehicle-treated animals (magnification $\times 400$ )

$\mathrm{M}$

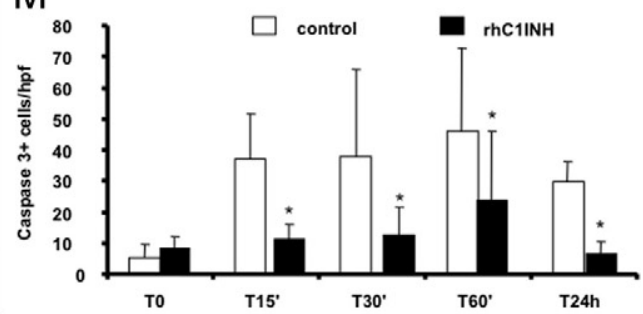

were also present in the glomerular capillaries (Figure 9C). On the contrary, control patients showed no C4d deposits (Figure 9D).

To determine whether $\mathrm{C} 4 \mathrm{~d}$ deposits were due to activation of classical or lectin pathways, we performed double staining for $\mathrm{C} 1 \mathrm{~g} / \mathrm{C} 4 \mathrm{~d}$ and $\mathrm{MBL} / \mathrm{C} 4 \mathrm{~d}$. Patients with DGF had co-deposition of both C1q and C4d (Figure 9, E, $\mathrm{G}$, and I), indicating that activation of complement occurred via the classical pathway. We also observed a clear colocalization of MBL and C4d (Figure 9, F, H, and J), suggesting the concurrent activation of the lectin pathway.

\section{Discussion}

In the present study we demonstrated for the first time that activation of the complement system occurs with the involvement of both classical and lectin pathways in a swine model of renal ischemia-reperfusion injury. We demonstrated that therapeutic inhibition of classical and lectin pathways by rhC1INH produced a significant reduction in complement deposition, with decreased recruitment of infiltrating inflammatory cells and tubulointer- stitial damage. Finally, we demonstrated that these two pathways were also activated in renal transplant recipients suffering from DGF.

DGF is the primary early complication seen in kidney transplant recipients, affecting more than $25 \%$ of patients. ${ }^{1}$ This condition is associated with an increased incidence of acute rejection episodes and worse longterm graft survival. In addition, the increasing use of expanded criteria donors inevitably results in a significant increase in the incidence of DGF, with the foreseeable consequences for the National Health Systems of increasing costs for kidney transplantation programs. To date we do not have specific therapeutic strategy to prevent DGF or to reduce its length.,17 Thus, this early post-transplant condition remains a significant concern for transplant physicians. An increasing amount of evidence derived from animal models suggests that the injury secondary to the ischemia-reperfusion process might play a pivotal role in the pathogenesis of this form of acute renal failure. ${ }^{1}$

One of the most prominent events occurring in ischemia-reperfusion is activation of the complement cas- 

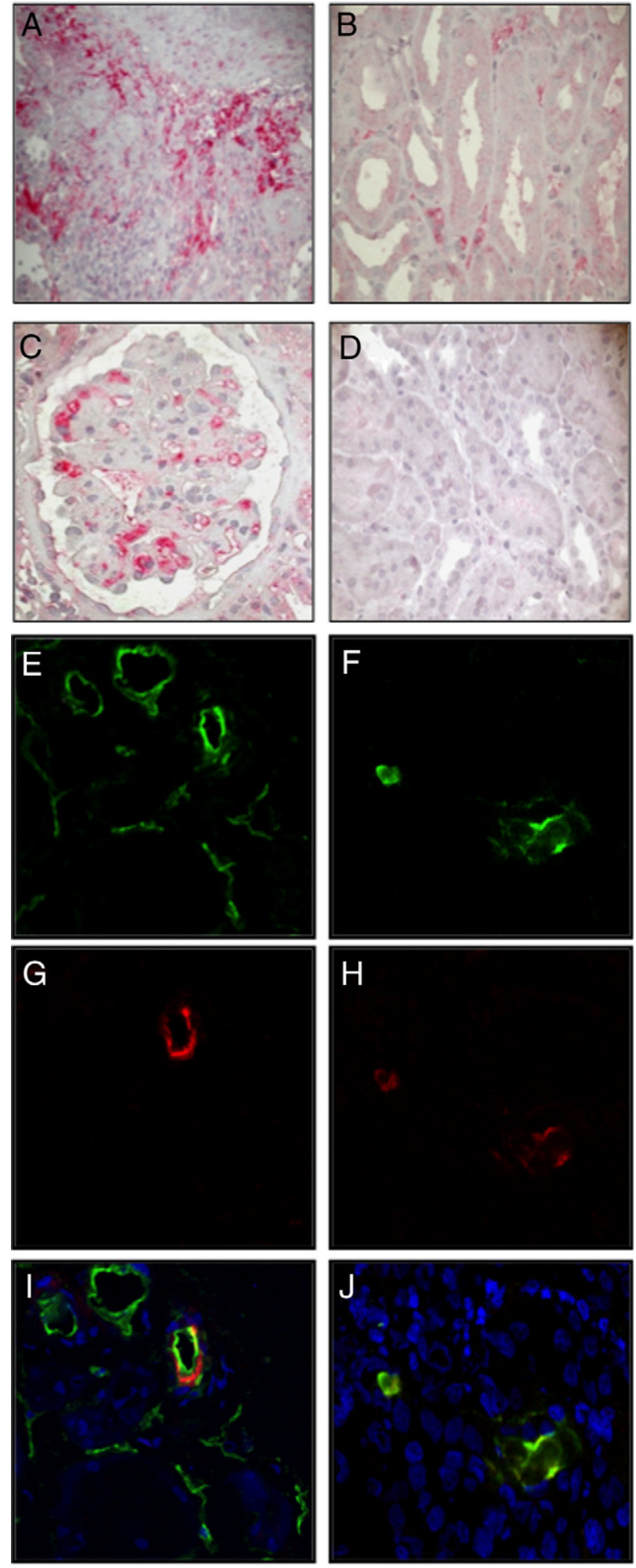

Figure 9. C4d deposition in graft biopsies of patients with DGF. C4d deposits were evaluated by immunohistochemistry on paraffin-embedded graft tissue as described in the methods section. C4d deposits were observed in patients with DGF (A, B, and $\mathbf{C}$ ) at interstitial (A), peri-tubular capillary (B), and glomerular capillary (C) level, whereas no C4d was found in control grafts (D). Co-localization of C4d with C1q $(\mathbf{E}-\mathbf{G}-\mathbf{I})$ and $\mathrm{MBL}(\mathbf{F}-\mathbf{H}-\mathbf{J})$ was investigated by immunofluorescence/confocal microscopy. C4d (green, E) colocalized with $\mathrm{C} 1 \mathrm{q}$ (red, G) at peri-tubular capillary sites (merge, I). C4d deposits (green, F) co-localized with MBL (red, $\mathbf{H}$ ) at the same site (merge, J). TO-PRO-3 (blue) was used to stain nuclei. Original magnifications were either $(\mathbf{A}-\mathbf{D}) \times 400$ or $(\mathbf{E}-\mathbf{J}) \times 630$. cade. ${ }^{4,5,18,19}$ The involvement of complement has been shown in several animal models, where deficiency in complement components significantly reduced the damage associated with ischemia-reperfusion (reviewed by Sacks et al). ${ }^{4}$ In agreement with these observations, the use of complement inhibitors was effective in limiting ischemia-reperfusion damage in normal animals. ${ }^{9,10}$ These data strongly suggest that the inhibition of complement may represent a potential target for preventing tissue damage. ${ }^{6,11}$

Interestingly, data available so far indicate that, in contrast to ischemia-reperfusion in the intestine, heart, and lung, complement activation due to ischemia-reperfusion in kidneys occurs almost exclusively through the alternative pathway. ${ }^{4,5,14,19}$ C4 and Ig deficient mice were not protected from ischemia-reperfusion injury.,20 On the contrary, factor B deficient mice were resistant to ischemia-reperfusion-induced renal damage. ${ }^{21}$ Taken as a whole, these observations indicate that neither the classical nor the lectin pathway of complement is involved in renal injury due to ischemia-reperfusion. However, all of the studies present in the literature were conducted in rodents and, so far, no data are available from larger animals.

In our swine model of renal ischemia-reperfusion injury, we found C4d deposits primarily present at the peritubular and glomerular capillary levels, indicating that the endothelial cells might play a pivotal role in the activation of complement. Ischemia can induce a lower resistance to complement activation in endothelial cells, leading to presentation of complement-activating surfaces and autoantigens. ${ }^{22} \mathrm{MBL}$ can bind to exposed cytokeratin on hypoxic endothelial cells, causing local activation of the complement cascade through the lectin pathway. Indeed, it has been shown that patients with high circulating concentrations of MBL have a poor outcome after renal transplantation. ${ }^{23}$ Moreover, C4d is actually seen as a specific marker of antibody-mediated classical pathway activation, ${ }^{24}$ being stable at the renal level for a long period of time because of covalently linkages. On the contrary, in our model we showed that C4d deposition was present in the early period after ischemia-reperfusion damage and disappeared at 24 hours postreperfusion and, in this setting, was mainly due to the activation of the lectin pathway. This led us to hypothesize that complement activation after ischemiareperfusion on ischemic or necrotic cells is not sustained in the long term, since these cells can be efficiently cleared by mononuclear phagocytes by 24 hours. This is confirmed by the fact that, in the swine model, we observed the disappearance of C5b-9 and a significant reduction of $\mathrm{C} 4 \mathrm{~d}$ deposition at 24 hours. This transient deposition of $\mathrm{C} 4 \mathrm{~d}$ in the animal model might also explain the focal deposition of this complement component observed 7 to 10 days after reperfusion in transplant recipients as well as the observation that C4d could not be detected in all DGF patients.

On the basis of the data on C4d deposition in our model, we investigated whether rhC1INH, a drug currently used in preclinical trials in patients suffering from hereditary angioedema due to genetic deficiency of 
$\mathrm{C} 1 \mathrm{INH},{ }^{25,26}$ was able to interfere with complement activation in renal ischemia-reperfusion injury. Previous research has shown that $\mathrm{C} 1 \mathrm{INH}$ reduces complement activation with significant protection of the myocardium and brain from ischemic damage. ${ }^{27-30}$ Moreover, $\mathrm{C} 1 \mathrm{INH}$ limited leukocyte adhesion and neutrophil infiltration in a model of ischemia-reperfusion in the liver. ${ }^{31-33}$ We observed that rhC1INH was very effective in limiting complement activation in renal tissue, as showed by the dramatic reduction of $\mathrm{C} 4 \mathrm{~d}$ and $\mathrm{C} 5 \mathrm{~b}-9$ deposition. It is well known that early activation of complement leads to the release of active substances including C3a and C5a that can increase the recruitment of inflammatory cells. ${ }^{6,10,34}$ As expected, pigs treated with rhC11NH showed reduced infiltrating CD163+ monocyte/macrophages and SWC3a+ dendritic cells. Importantly, we observed that infiltrating T lymphocytes were also significantly reduced in treated pigs. We hypothesize that this effect might be the result of a double action of $\mathrm{rhC} 1 \mathrm{INH}$. Indeed, this serine protease inhibitor, next to the inhibition of complement activation, it has been shown to interfere with selectin/integrin interaction, therefore reducing the recruitment of leukocytes at the site of inflammation. ${ }^{30}$

In addition, it is well know that complement activation can induce resident cell apoptosis and necrosis by caspase activation through mediators such as C5b-9. ${ }^{35-38}$ Indeed, we found the appearance of caspase-3+ tubular epithelial cells in the tubulointerstitial region in untreated pigs. The inhibition of complement by rhC1INH in this setting was sufficient to limit the induction of apoptosis to very low level, thus preventing ischemia-reperfusion-induced tubular damage. The reduced presence of infiltrating $T$ cells and dendritic cells associated with a marked decrease of tubular cell damage might have a beneficial immunological effect in the setting of renal transplantation, limiting the immunogenicity of the injured kidney, and reducing both direct and indirect alloantigen presentation. Despite the significant protective effects demonstrated by this drug in preserving the histology of ischemic kidney in our model, we believe that further clinical investigations are warranted to evaluate the effects of rhC1INH infusion on renal function in ischemia-reperfusion-induced renal injury.

Finally, in the present study we identified clear signs of involvement of the classical and lectin pathways in patients with DGF. The colocalization of C4d with both $\mathrm{C} 1 \mathrm{q}$ and $\mathrm{MBL}$ in graft biopsies obtained from these patients indicated that both these pathway were activated on peritubular capillaries, within the interstitium, and on the glomerular endothelium. Importantly, none of the patients showed histological signs of acute rejection, although we cannot completely rule out the possibility that in some patients C4d deposition might be due to the presence of circulating antibodies, undetectable by our standard methodology. However, it should be taken into consideration that none of the patients was treated for acute rejection and all of them completely recovered graft function. In addition, our data are in agreement with previous demonstration of $\mathrm{C} 4 \mathrm{~d}$ or MBL deposits in human transplanted kidney with early graft dysfunction ${ }^{39}$ or primary non-function. ${ }^{40}$ To our knowledge, this is the first evidence of activation of classical and lectin pathway of complement in the specific population of DGF patients. Our data seems to be conflicting with a previous report, which, however, analyzed complement activation in clearly different population of transplanted patients. ${ }^{41-43}$ In particular, Haas et al ${ }^{41}$ reported no $\mathrm{C} 4 \mathrm{~d}$ deposits in postimplantation biopsies performed 1 hour after reperfusion. Although most of their cases were transplantations from living donors, with a very limited cold ischemia time, they also reported cases of deceased donor kidney transplantations with over 30 hours of cold ischemia. The human model used by these authors closely resembles our experimental model, however also in our study we observed few differences between the complement activation observed in DGF patients and in the swine model. Indeed, in one third of the human subjects included in our study C4d staining was observed at 7 to 15 days after transplantation, whereas in the swine model most of the specific deposits were gone by 24 hours. This observation would suggest a different kinetics of complement activation in human subjects. Thus, it is conceivable that the one hour postimplantation biopsy performed by Haas et al may have missed the complement priming induced by ischemia-reperfusion in this setting. These apparently conflicting results from different studies with limited patients' populations suggest the need for a large observational study to confirm the value and the specificity of $\mathrm{C} 4 \mathrm{~d}$ deposition in peritransplant graft biopsies.

In conclusion, our data suggest a key role for therapeutic inhibition of classical and lectin pathway of complement activation in the prevention of ischemia-reperfusion injury in the transplanted kidney. On the basis of our observation, the use of rhC1INH deserves further clinical studies in transplant recipients at high risk for DGF, since it may reduce the incidence and/or improve the clinical course of this common early post-transplant complication, potentially influencing long-term graft function and survival.

\section{Acknowledgments}

We thank Claudia Curci, Nicoletta Fiore, Michelangelo Corcelli, and Vincenzo Gesualdo, from the Renal, Dialysis, and Transplantation Unit, for the excellent technical assistance and Mariella Mastronardo for her editorial assistance and language revision of the manuscript.

\section{References}

1. Perico N, Cattaneo D, Sayegh MH, Remuzzi G: Delayed graft function in kidney transplantation. Lancet 2004, 364: 1814-1827

2. Gueler F, Gwinner W, Schwarz A, Haller H: Long-term effects of acute ischemia and reperfusion injury. Kidney Int 2004, 66: 523-527

3. Peeters P, Vanholder R: Therapeutic interventions favorably influencing delayed and slow graft function in kidney transplantation: mission impossible? Transplantation 2008, 85: S31-S37

4. Sacks SH, Chowdhury P, Zhou W: Role of the complement system in rejection. Curr Opin Immunol 2003, 15: 487-492

5. Li K, Sacks SH, Zhou W: The relative importance of local and systemic complement production in ischaemia, transplantation and other pathologies. Mol Immunol 2007, 44: 3866-3874

6. Ricklin D, Lambris JD: Complement-targeted therapeutics. Nature Biotechnol 2007, 25: 1265-1275 
7. Walport MJ: Complement. First of two parts. N Engl J Med 2001, 344 1058-1066

8. Zhou W, Farrar CA, Abe K, Pratt JR, Marsh JE, Wang Y, Stahl GL, Sacks SH: Predominant role for C5b-9 in renal ischemia/reperfusion injury. J Clin Invest 2000, 105: 1363-1371

9. Thurman JM, Royer PA, Ljubanovic D, Dursun B, Lenderink AM, Edelstein CL, Holers VM: Treatment with an inhibitory monoclonal antibody to mouse factor B protects mice from induction of apoptosis and renal ischemia/reperfusion injury. J Am Soc Nephrol 2006, 17: 707-715

10. Arumugam TV, Shiels IA, Strachan AJ, Abbenante G, Fairlie DP, Taylor SM: A small molecule C5a receptor antagonist protects kidneys from ischemia/reperfusion injury in rats. Kidney Int 2003, 63: 134-142

11. Mollnes TE, Kirschfink M: Strategies of therapeutic complement inhibition. Mol Immunol 2006, 43: 107-121

12. Thorgersen EB, Ghebremariam YT, Thurman JM, Fung M, Nielsen EW, Holers VM, Kotwal GJ, Mollnes TE: Candidate inhibitors of porcine complement. Mol Immunol 2007, 44: 1827-1834

13. Davis AE, III, Mejia P, Lu F: Biological activities of C1 inhibitor. Mol Immunol 2008, 45: 4057-4063

14. Thurman JM: Triggers of inflammation after renal ischemia/reperfusion. Clin Immunol 2007, 123: 7-13

15. Seelen MA, Roos A, Wieslander J, Mollnes TE, Sjoholm AG, Wurzner R, Loos M, Tedesco F, Sim RB, Garred P, Alexopoulos E, Turner MW, Daha MR: Functional analysis of the classical, alternative, and MBL pathways of the complement system: standardization and validation of a simple ELISA. J Immunol Methods 2005, 296: 187-198

16. Loverre A, Capobianco C, Stallone G, Infante B, Schena A, Ditonno P, Palazzo S, Battaglia M, Crovace A, Castellano G, Ranieri E, Schena FP, Gesualdo L, Grandaliano G: Ischemia-reperfusion injuryinduced abnormal dendritic cell traffic in the transplanted kidney with delayed graft function. Kidney Int 2007, 72: 994-1003

17. Chatterjee PK: Novel pharmacological approaches to the treatment of renal ischemia-reperfusion injury: a comprehensive review. Naunyn Schmiedebergs Arch Pharmacol 2007, 376: 1-43

18. Zhang M, Alicot EM, Chiu I, Li J, Verna N, Vorup-Jensen T, Kessler B, Shimaoka M, Chan R, Friend D, Mahmood U, Weissleder R, Moore FD, Carroll MC: Identification of the target self-antigens in reperfusion injury. J Exp Med 2006, 203: 141-152

19. Zhang M, Takahashi K, Alicot EM, Vorup-Jensen T, Kessler B, Thiel S, Jensenius JC, Ezekowitz RA, Moore FD, Carroll MC: Activation of the lectin pathway by natural IgM in a model of ischemia/reperfusion injury. J Immunol 2006, 177: 4727-4734

20. Park P, Haas M, Cunningham PN, Bao L, Alexander JJ, Quigg RJ: Injury in renal ischemia-reperfusion is independent from immunoglobulins and T lymphocytes. Am J Physiol Renal Physiol 2002, 282: F352-F357

21. Thurman JM, Ljubanovic D, Edelstein CL, Gilkeson GS, Holers VM: Lack of a functional alternative complement pathway ameliorates ischemic acute renal failure in mice. J Immunol 2003, 170: 1517-1523

22. Collard CD, Montalto MC, Reenstra WR, Buras JA, Stahl GL: Endothelial oxidative stress activates the lectin complement pathway: role of cytokeratin 1. Am J Pathol 2001, 159: 1045-1054

23. Berger SP, Roos A, Mallat MJ, Fujita T, De Fijter JW, Daha MR: Association between mannose-binding lectin levels and graft survival in kidney transplantation. Am J Transplant 2005, 5: 1361-1366

24. Nickeleit V, Zeiler M, Gudat F. Thiel G, Mihatsch MJ: Detection of the complement degradation product C4d in renal allografts: diagnostic and therapeutic implications. J Am Soc Nephrol 2002, 13: 242-251

25. van Doorn MB, Burggraaf J, van Dam T, Eerenberg A, Levi M, Hack CE, Schoemaker RC, Cohen AF, Nuijens J: A phase I study of recombinant human $\mathrm{C} 1$ inhibitor in asymptomatic patients with hereditary angioedema. J Allergy Clin Immunol 2005, 116: 876-883

26. Choi G, Soeters MR, Farkas H, Varga L, Obtulowicz K, Bilo B,
Porebski G, Hack CE, Verdonk R, Nuijens J, Levi M: Recombinant human $\mathrm{C} 1$-inhibitor in the treatment of acute angioedema attacks. Transfusion 2007, 47: 1028-1032

27. De Simoni MG, Storini C, Barba M, Catapano L, Arabia AM, Rossi E, Bergamaschini L: Neuroprotection by complement (C1) inhibitor in mouse transient brain ischemia. J Cereb Blood Flow Metab 2003, 23 232-239

28. De Simoni MG, Rossi E, Storini C, Pizzimenti S, Echart C, Bergamaschini $\mathrm{L}$ : The powerful neuroprotective action of $\mathrm{C} 1$-inhibitor on brain ischemia-reperfusion injury does not require C1q. Am J Pathol 2004, 164 1857-1863

29. Storini C, Rossi E, Marrella V, Distaso M, Veerhuis R, Vergani C, Bergamaschini L, De Simoni MG: C1-inhibitor protects against brain ischemia-reperfusion injury via inhibition of cell recruitment and inflammation. Neurobiol Dis 2005, 19: 10-17

30. de Zwaan C, Kleine AH, Diris JH, Glatz JF, Wellens HJ, Strengers PF, Tissing M, Hack CE, Dieijen-Visser MP, Hermens WT: Continuous 48-h C1-inhibitor treatment, following reperfusion therapy, in patients with acute myocardial infarction. Eur Heart J 2002, 23: 1670-1677

31. Heijnen BH, Straatsburg IH, Padilla ND, Van Mierlo GJ, Hack CE, Van Gulik TM: Inhibition of classical complement activation attenuates liver ischaemia and reperfusion injury in a rat model. Clin Exp Immunol 2006, 143: 15-23

32. Inderbitzin D, Beldi G, Avital I, Vinci G, Candinas D: Local and remote ischemia-reperfusion injury is mitigated in mice overexpressing human C1 inhibitor. Eur Surg Res 2004, 36: 142-147

33. Bergamaschini L, Gobbo G, Gatti S, Caccamo L, Prato P, Maggioni M, Braidotti P, Di Stefano R, Fassati LR: Endothelial targeting with C1-inhibitor reduces complement activation in vitro and during ex vivo reperfusion of pig liver. Clin Exp Immunol 2001, 126: 412-420

34. Sozzani S, Sallusto F, Luini W, Zhou D, Piemonti L, Allavena P, Van Damme J, Valitutti S, Lanzavecchia A, Mantovani A: Migration of dendritic cells in response to formyl peptides, C5a, and a distinct set of chemokines. J Immunol 1995, 155: 3292-3295

35. Nauta AJ, Daha MR, Tijsma O, van de WB, Tedesco F, Roos A: The membrane attack complex of complement induces caspase activation and apoptosis. Eur J Immunol 2002, 32: 783-792

36. Pippin JW, Durvasula R, Petermann A, Hiromura K, Couser WG Shankland SJ: DNA damage is a novel response to sublytic complement C5b-9-induced injury in podocytes. J Clin Invest 2003, 111 877-885

37. Nangaku M, Pippin J, Couser WG: Complement membrane attack complex (C5b-9) mediates interstitial disease in experimental nephrotic syndrome. J Am Soc Nephrol 1999, 10: 2323-2331

38. Hughes J, Nangaku M, Alpers CE, Shankland SJ, Couser WG Johnson RJ: C5b-9 membrane attack complex mediates endothelial cell apoptosis in experimental glomerulonephritis. Am J Physio Renal Physiol 2000, 278: F747-F757

39. Feucht HE, Schneeberger H, Hillebrand G, Burkhardt K, Weiss M, Riethmuller G, Land W, Albert E: Capillary deposition of C4d complement fragment and early renal graft loss. Kidney Int 1993, 43 1333-1338

40. de Vries B, Walter SJ, Peutz-Kootstra CJ, Wolfs TG, van Heurn LW, Buurman WA: The mannose-binding lectin-pathway is involved in complement activation in the course of renal ischemia-reperfusion injury. Am J Pathol 2004, 165: 1677-1688

41. Haas M, Ratner LE, Montgomery RA: C4d staining of perioperative renal transplant biopsies. Transplantation 2002, 74: 711-717

42. Sund S, Hovig T, Reisaeter AV, Scott H, Bentdal O, Mollnes TE: Complement activation in early protocol kidney graft biopsies after living-donor transplantation. Transplantation 2003, 75: 1204-1213

43. Imai N, Nishi S, Alchi B, Ueno M, Fukase S, Arakawa M, Saito K, Takahashi K, Gejyo F: Immunohistochemical evidence of activated lectin pathway in kidney allografts with peritubular capillary C4d deposition. Nephrol Dial Transplant 2006, 21: 2589-2595 